\title{
TRYPANOSOMA CRUZI: STRAIN SELECTION BY DIFFERENT SCHEDULES OF MOUSE PASSAGE OF AN INITIALLY MIXED INFECTION
}

\author{
MARIA P. DEANE, ${ }^{*}$ REGINA H.R. MANGIA, * NEIZE M. PEREIRA, * HOOMAN MOMEN, ${ }^{*}$ \\ ANTONIO M. GONÇALVES ** \& CARLOS M. MOREL **
}

\begin{abstract}
From an initial double infection in mice, established by simultaneous and equivalent inocula of bloodstream forms of strains $Y$ and $F$ of Trypanosoma cruzi, two lines were derived by subinoculations: one $(W)$ passaged every week, the other $(M)$ every month. Through biological and biochemical methods only the $Y$ strain was identified at the end of the 10th and 16th passages of line $W$ and only the $F$ strain at the 2nd and 4th passages of line $M$. The results illustrate strain selection through laboratory manipulation of initially mixed populations of $\mathrm{T}$. cruzi.
\end{abstract}

We have demonstrated (Deane et al., 1984) that when mice are doubly infected with two different strains of Trypanosoma cruzi, either strain may be selected in the reisolates by varying the scheme used for the inoculations, reinoculations and reisolation. In these experiments, mice were first inoculated with either the $\mathrm{Y}$ or $\mathbf{F}$ strain of $T$. cruzi followed by a second inoculum with the other strain. This inoculum was made at various time intervals and differed quantitatively and qualitatively (bloodstream or culture trypomastigotes) from the first one.

We now describe how strain selection of an initial double infection, established by simultaneous and equivalent inocula of both strains, may be achieved by simply using different intervals between mouse passages.

\section{MATERIAL AND METHODS}

The parasites: in a previous paper we gave details of the origin of the $\mathrm{Y}$ and $\mathrm{F}$ strains of $T$. cruzi, their routine maintenance in our laboratory and the characteristic pattern of infection they produce in mice, as well as details of the biochemical markers we have found useful for their identification: variation in the glucosephosphate isomerase (GPI) isozyme and in the kDNA profile produced by the EcoRI restriction endonuclease (Deane et al., 1984).

Inoculation, passages and reisolations: adult female outbred mice and the intraperitoneal route were used throughout. The primary inoculation was of an in-vitro mix ture of bloodstream trypomastigotes (BST) of the $\mathrm{Y}$ and $\mathrm{F}$ strains in equivalent numbers, amounting to a total of $10^{4}$ flagellates per mouse. The donor mice were from those used for maintenance, bled on the 7th or 28th day of infection according to the routine of passages for each strain. From this first (mixed) inoculation, two lines of passages were established: one - "W" - every 7th day (or weekly), the other - "M" - every 28th day (or monthly). These passages were of $10^{5}$ BST per mouse, in groups of 5-6 mice. The following reisolations of the parasites were made through hemocultures in NNN medium: W1, W2 and W3 at the end of the 1st, 10th and 18th weekly passages of line $\mathrm{W} ; \mathrm{M} 1$ and M2, at the end of the 8th and 16 th weeks, corresponding to the 2nd and 4 th monthly passages of line $\mathrm{M}$.

At the passages corresponding to reisolations W3 and W2, 10-12 mice were inoculated (instead of the usual 5-6) and some were used to establish parasitemia curves and mortality.

Techniques: all technical procedures were as described previously (Deane et al., 1984). RESULTS

The passages of the $M$ line were started with some difficulty due to early death of the mice, probably because of the predominant presence of the more virulent Y strain BST in the inocula. However, by taking the blood of 1-2 mice that survived longer among those of line $\mathrm{W}$, we soon had groups with animals surviving the required 4 weeks and from these the $M$ line was established.

In the cultures corresponding to the $W 1$ reisolation the presence of both the $Y$ and $F$ strains was detected by both markers, the GPI isozyme and the kDNA restriction profile. However, only the Y strain was identified in the reisolates W2 and W3 and only the F strain in the reisolates M1 and M2 (Figs. 1 and 2). Parasitaemia and mortality produced in mice by reisolates $\mathrm{W} 3$ and $\mathrm{M} 2$ were typical of $\mathrm{Y}$ and $\mathrm{F}$ infections, respectively (Fig. 3).

This work was supported by grants from the Conselho Nacional de Desenvolvimento Científico e Tecnológico, CNPq, Brazil, from the UNDP/WORLD BANK/WHO Special Programme for Research and Training in Tropical Diseases and Financiadora de Estudos e Proje tos, FINEP, Brazil.

Instituto Oswaldo Cruz, *Departamento de Protozoologia, * Departamento de Bioquímica e Biologia Molecular, Caixa Postal 926, 20000, Rio de Janeiro, RJ, Brazil.

Received for publication April 4th and accepted April 30th, 1984. 


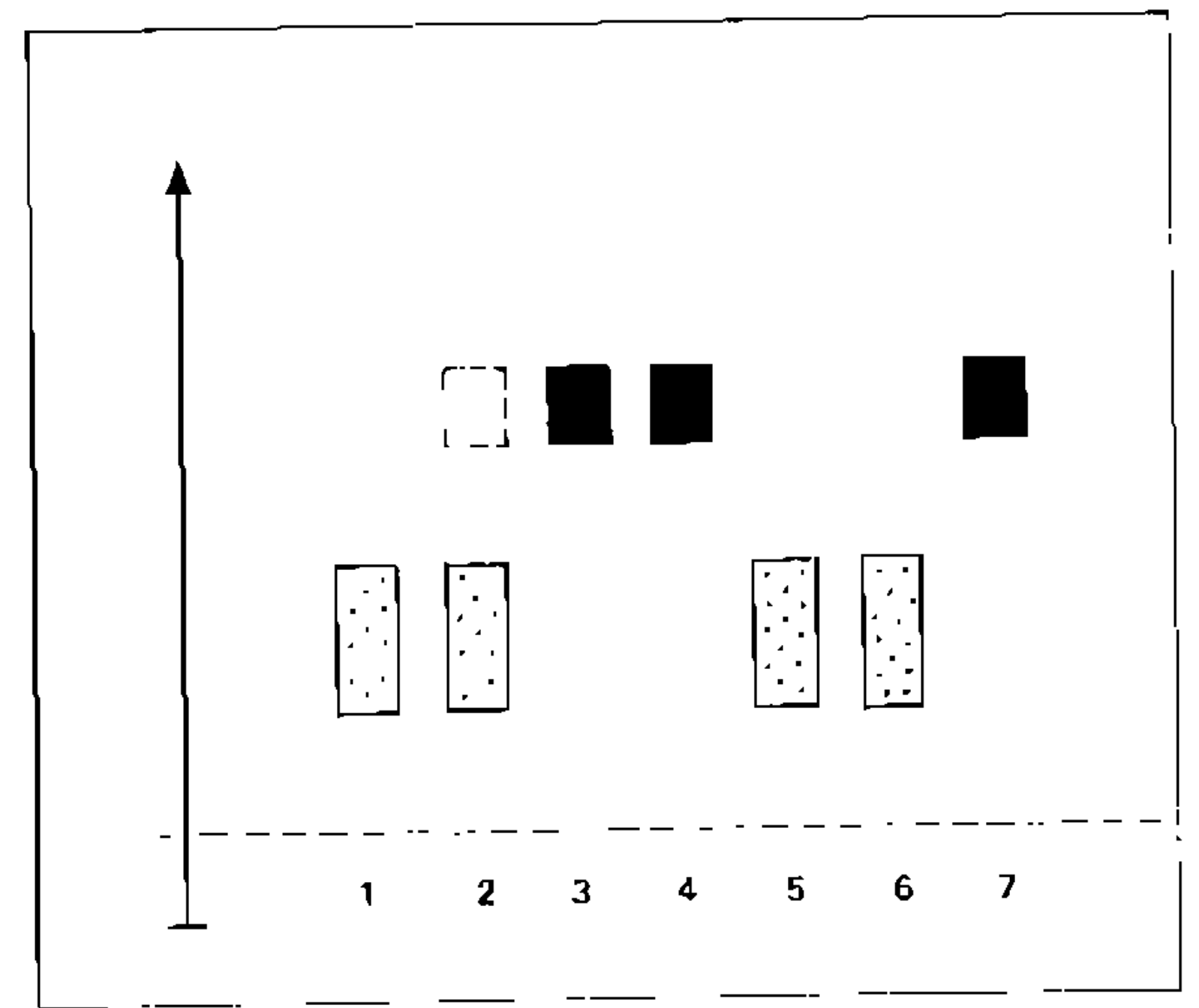

Fig. 1: diagram of electrophorectic profiles in $1 \%$ agarose gel. of reisolates $W_{1}, W_{2}, W_{3}$, $\mathrm{M}_{1}$ and $\mathrm{M}_{2}$ (lanes 2-6. respectively) after treatment for the glucose-phosphate-isomerase (G.P.I.) isozyme. Lanes 1 and 7: controls $I:$ and $Y$.

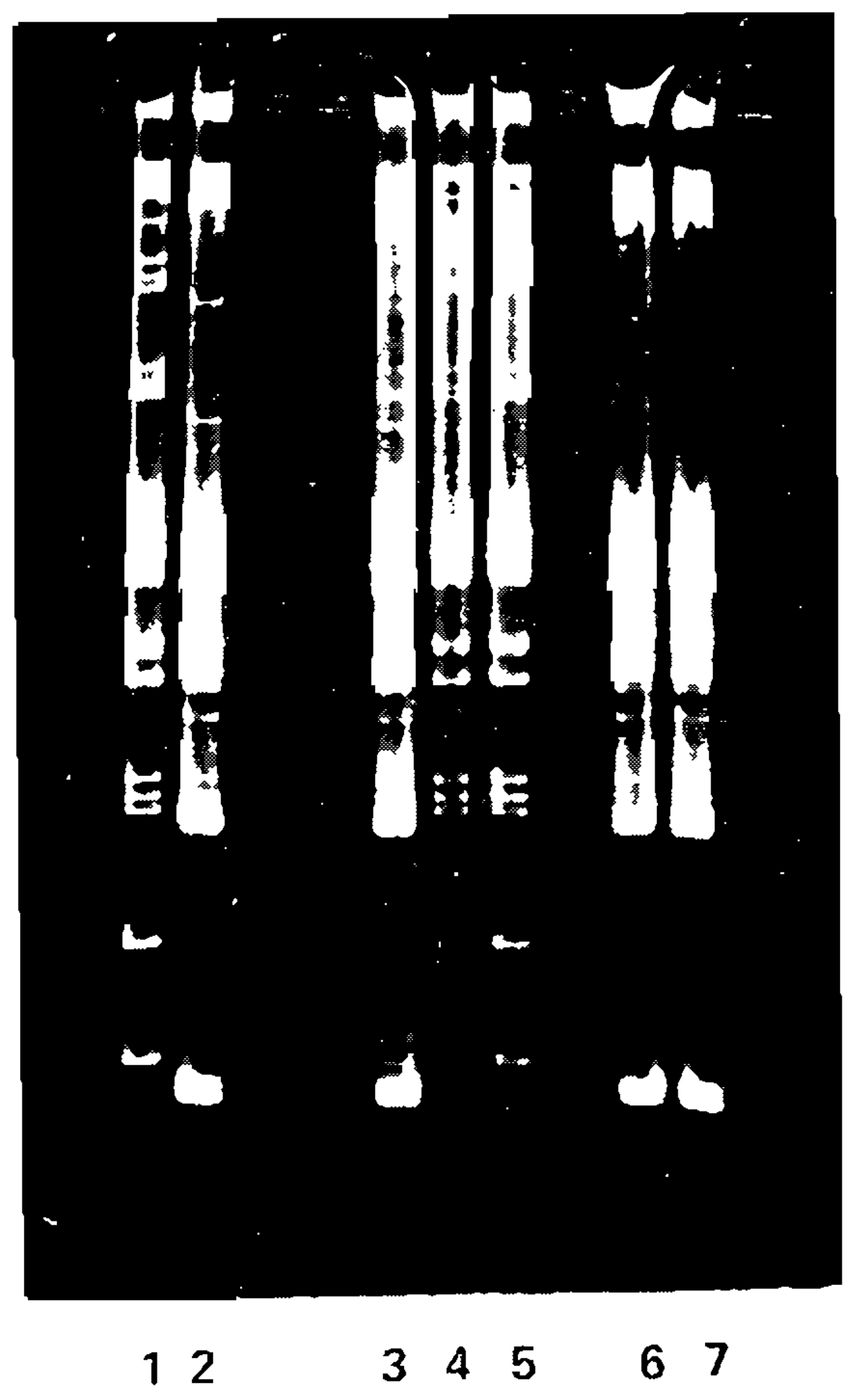

Fig, 2: schizodeme analysis of parasites in reisolates $W_{1}, W_{2}, W_{3}, M_{1}$ and $M_{2}$ (lanes $3-5$, respectively) obtained after digestion by the F,coRI endonuclease. Lanes 1 and 2 , controls $Y$ and $F$.

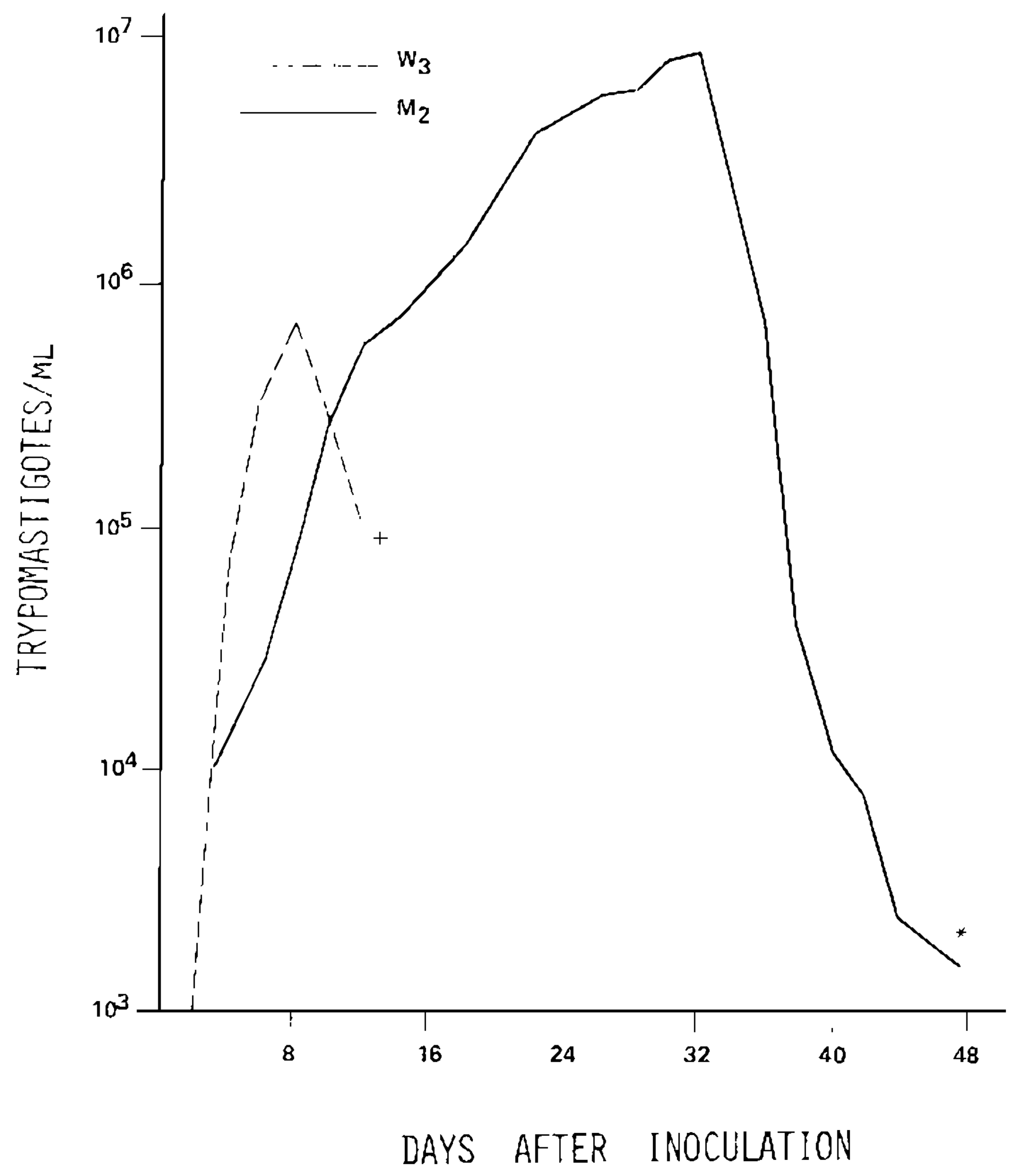

Fig. 3: parasitemia and mortality in mice inoculated with reisolates $W_{3}$ and $\mathrm{M}_{2}$ (averages from 6 mice in each group). + all mice de ad: * all mice alive. 


\section{DISCUSSION}

As aforementioned, both the $\mathrm{Y}$ and $\mathrm{F}$ strains were detected at the end of the first weekly (WI) passage and probably a mixed population kept being transplanted from mouse to mouse at least for some time. However, the significant result of these experiments is that, in the final isolates, only one of the strains was identified by the methods commonly used in $T$. cruzi strain characterization.

Strain selection from an originally mixed infection is possibly related, at least in part, to intrinsic differences in growth rates, such as those described previously (Dvorak et al., 1980, 1982; Engel et al., 1982) in cultures of several cloned isolates of $T$. cruzi. Other factors have been discussed (Deane et al., 1984) and are being investigated.

We again emphasize the importance of the selective pressures to which populations of $T$. cruzi isolated from natural sources may be submitted through laboratory manipulations and the necessity of keeping this is mind when trying to correlate strain of the parasite with clinical and pathological manifestations of the disease.

\section{RESUMO}

De uma infecção inicialmente dupla em camundongo, estabelecida por inóculo simultâneo e equivalente de formas sangüíneas das cepas $\mathrm{Y}$ e $\mathrm{F}$ de Trypanosoma cruzi, duas linhagens foram originadas por subinoculações: uma (W) passada cada semana, a outra (M) cada mês. Por métodos biológicos e bioquímicos apenas a cepa $Y$ foi identificada ao fim da $10^{\mathrm{a}}$ e $16^{\mathrm{a}}$ passagens da linhagem $W$ e apenas a cepa $F$ na $2^{\mathrm{a}}$ e 4 a passagens de linhagem M. Os resultados demonstram a seleção de cepas através de manipulação em laboratório de populações inicialmente mistas de T. cruzi.

\section{ACKNOWLEDGEMENTS}

The Authors are grateful to Valquíria da Silva Trajano and Nédia Saad Nehme for technical assistance.

\section{REIERENCES}

DEANE, M.P.; SOl;SA, M.A.: PF.REIRA, N.M.; GONÇALVHS. A.M.: MOMF, H. \& MOREL. C.M., 1984. Trypanosoma cruzi: Inoculation schedules and reisolation methods select individual strains from doubly infected mice. as demonstrated by schizodeme and zymodeme analyses. J. Protozool. in press.

IVVORAK. J.A.; HARTMAN, D.L. \& MILFS. M.A., 1980. Trypanosoma cruzi: Correlation of growth kinetics to zymodeme type in clones derived from various sources. J. Protozool. $27: 472.474$.

DVORAK. J.A.: HAI.L, T.E.; CRANF;, M.St.J.; ENGFL, J.C.; McDANIFL, J.P. \& URIFGAS, R.. 1982. Trypanosoma cruzi: flow cytometric analysis. I. Analysis of total DNA/organism by means of mitramycin-induced fluorescence. J. Protozool. $29: 430-437$.

ENGEL, J.C .: DVORAK, J.A.; SEGURA, L.L. \& CRANE. M.St.J., 1982. Trypanosoma cnuzi: biological characterization of 19 clones derived from two chronic chagasic patients. I. Growth kinetics in liquid medium. J. Protozool. $29: 555$ 560 . 